О.М. Литвяк ${ }^{1}$, С.В. Комар ${ }^{2}$

${ }^{1}$ Національний університет циивільного захисту України, Харків

${ }^{2}$ Харківський наџіональний університет Повітряних Сил ім. І. Кожедуба, Харків

\title{
ПРОБЛЕМИ НАЗЕМНИХ ВИПРОБУВАНЬ ТУРБОВАЛЬНИХ ГАЗОТУРБІННИХ ДВИГУНІВ ТИПУ ТВЗ-117
}

\begin{abstract}
При наземних випробуваннях газотурбінних двигунів ТВ3-117 на гідравлічних гальмівних установках часто реєструють автоколивання частоти обертання ротора вільної турбіни $i$ параметрів турбокомпресора в області роботи регулятора обертів вільної турбіни. Однією з причин розвитку автоколивань в системі автоматичного регулювання вільної турбіни є невідповідність завантажувальних характеристик гідрогальмівної установки завантажувальним характеристикам несучого гвинта вертольота. При наземних випробуваннях об'єктом регулювання є вільна турбіна з підключеним ротором гідрогальма. При роботі двигуна в складі силової установки вертольота об'єктом регулювання є вільна турбіна з підключеним ротором несучого гвинта. Зміна параметрів об'єкта регулювання без відповідної корекиії параметрів регулятора може призводити до незадовільної динаміки системи автоматичного регулювання. Іншою причиною розвитку автоколивань є нелінійність характеристик елементів системи автоматичного регулювання. Розроблено математичну модель системи автоматичного регулювання обертів вільної турбіни, щчо враховує нелінійні особливості характеристик реальних регуляторів. Проведено розрахункові дослідження впливу розриву статичної характеристики $і$ зони нечутливості регулятора на розвиток автоколивань в системі автоматичного регулювання обертів вільної турбіни при наземних випробуваннях вертолітного двигуна. Дано рекомендації щуодо вибору параметрів регулятора обертів вільної турбіни для запобігання виникненню і розвитку автоколивань обертів турбокомпресора $і$ вільної турбіни.
\end{abstract}

Ключові слова: турбовальный ГТД, вільна турбіна, несучий гвинт вертольоту, гідрогальмо, регулятор обертів вільної турбіни, статична характеристика регулятора, автоколивання.

\section{Вступ}

Постановка проблеми. При наземних випробуваннях турбовальних газотурбінних двигунів типу ТВ3-117 (Україна) з насосом-регулятором типу НР-3 (Україна) в області роботи регулятора обертів вільної турбіни (РОВТ) часто фіксується несправність, яка проявляється як сталі коливання (автоколивання) параметрів двигуна. В окремих випадках має місце безперервне зростання амплітуди коливань (нестійка робота) аж до спрацювання автоматичної системи захисту двигуна. Причинами автоколивань в складних системах автоматичного регулювання є: невідповідність параметрів регулятора об'єкту регулювання; розрив характеристик елементів системи автоматичного регулювання; надлишковий коефіцієнт підсилення регулятора [1].

Слід зазначити, що при роботі двигуна в складі силової установки вертольота вільна турбіна (ВТ) приводить в обертання несучий гвинт вертольота (НГ). У цьому випадку об'єктом регулювання є вільна турбіна $з$ підключеним гвинтом (ВТ + НГ). Наземні випробування турбовальних газотурбінних двигунів найчастіше виконуються на гідрогальмівних установках (ГГУ), які використовують для поглинання (утилізації) потужності, що виробляється вільною турбіною (ВТ). У цьому випадку об'єктом регулювання є вільна турбіна 3 підключеним гідрогальмом (ВТ + ГГ). Експериментально встановлено, що завантажувальні характеристики ГГУ без відповідної автоматизації іiї завантаженням не відповідають завантажувальним характеристикам НГ вертольота [2]. Крім того, експериментальні дослідження реальних характеристик РОВТ насоса-регулятора HР-3 показали, що вони можуть бути нелінійними і можуть містити зону нечутливості, злами і розриви першого роду [3].

Нелінійність характеристик РОВТ, з одного боку, і невідповідність динамічних параметрів гідрогальмівної установки динамічним параметрам несучого гвинта вертольота при наземних випробуваннях турбовальних ГТД, з іншого боку, можуть бути причинами розвитку автоколивань параметрів двигуна в області роботи регулятора обертів вільної турбіни.

Таким чином, існує проблема виникнення автоколивань у системі автоматичного регулювання обертів вільної турбіни турбовальних газотурбінних двигунів типу ТВ3-117 з насосом-регулятором НР-3 при наземних випробуваннях на гідрогальмівних установках.

Аналіз останніх досліджень і публікацій. Загальні підходи дослідження динаміки систем автоматичного регулювання (САР) на несталих режимах 
викладені в [4]. Розглядаються рівняння динаміки двигуна ГТД, власна стійкість і вплив зовнішніх умов на динамічні параметри. Наведені структурні і структурно-динамічні схеми різних систем автоматичного регулювання. Представлені методи є основою дослідження динаміки систем автоматичного регулювання в пакетах сучасних прикладних програм. У роботах, присвячених нелінійній динаміці [5-6], викладаються теоретичні основи автоколивань в системах автоматичного управління. Відзначено, що коливання в контурах управління технологічним процесом - дуже поширена проблема. Коливання часто вказують на більш серйозну проблему, ніж нерегулярна мінливість. Показано, що причинами автоколивань є суттєво нелінійні особливості характеристик елементів автоматичних систем. До таких істотно нелійних особливостей слід віднести зони нечутливості, розриви і злами характеристик елементів. Під розривом розуміється ступенева зміна параметра. А під зламом - різка зміна кута нахилу характеристики елемента.

Велика увага приділяється розвитку теоретичних основ аналізу стійкості і автоколивань в сучасних нелінійних системах. В [7] розглядається можливість розвитку автоколивань в нелінійних системах автоматичного управління на основі аналізу дійсних коренів спеціальним чином побудованих алгебраїчних рівнянь. Такий підхід дійсно розширює можливості попереднього аналізу розвитку автоколивань, але не дозволяє враховувати нелінійні особливості реальних агрегатів. У статті [8] досліджені нелінійні коливальні процеси в системах зі змінними параметрами із запізненням. Наявність запізнювання додатково ускладнює завдання. Запропоновано методику визначення параметрів, при яких виникають автоколивання. Але в цілому розглядається лінійна задача 3 ланкою запізнювання. Змінний коефіцієнт підсилення для кожної розглянутої точки до уваги не береться.

Методологічні основи діагностики автоколивань в виробничих процесах детально розглянуті в [9]. Показані першопричини, що призводять до автоколивань: коливання можуть бути викликані занадто високим коефіцієнтом підсилення регулятора, коливальними збуреннями або іншими взаємодіями. Дуже поширеною причиною коливань є тертя в регулюючих клапанах. Формулюються цілі діагностики автоколивань, обговорюються методи для виявлення коливань в змінних процесах.

Практичне застосування діагностики автоколивань знайшло відображення в роботах [10-11]. У роботі [10] розглянуто вплив залипання керуючого клапана на нелінійність системи. Показано, що нелінійні характеристики клапана можуть призводити до нестійкості і розвитку автоколивань в системі управління. Проте методологія діагностики даного дефекту в роботі не повністю розкрита. В [11] наводиться частотний метод аналізу залипання керуючого клапана в багатоконтурних системах управління. У даній роботі основна увага приділяється частотному аналізу коливань, викликаних залипанням клапану. Пропонується механізм компенсації коливань за допомогою настройки зовнішнього і внутрішнього контролера. В [12] відзначається, що будьяка реальна система управління містить один або кілька пов'язаних істотно нелінійних елементів. Наявність таких елементів в системах автоматичного управління викликає такі несприятливі ефекти, як зменшення запасу стійкості, появу автоколивань, збільшення статичної похибки. У статті пропонується програмний модуль для компенсації зони нечутливості. Можливість компенсації розриву характеристики регулятора не розглядається. В [13] повідомляється про проектування та розробку експертної системи діагностики несправностей складних систем.

Метою статті є виявлення причин виникнення автоколивань у системі автоматичного регулювання обертів вільної турбіни турбовальних двигунів типу TB3-117, що дозволить розробити рекомендації щодо їх усунення. Для досягнення поставленої мети потрібно вирішити наступні завдання:

1. Розробити математичну модель для дослідження динаміки системи автоматичного регулювання обертів вільної турбіни турбовального ГТД з урахуванням особливостей реальних характеристик POBT.

2. Виявити закономірності впливу динамічних параметрів елементів системи автоматичного регулювання обертів вільної турбіни $\mathrm{CAP}\left(\mathrm{n}_{\mathrm{BT}}\right)$ на динамічні характеристики турбовальних газотурбінних двигунів вертольотів.

3. Встановити причини виникнення автоколивань в системі автоматичного регулювання обертів вільної турбіни турбовального двигуна типу ТВ3117 при його наземних випробуваннях на гідрогальмівній установці.

\section{Виклад основного матеріалу}

Математична модель динаміки САР $\left(\mathrm{n}_{\mathrm{BT}}\right)$ турбовального двигуна включає:

- динамічну модель ротора турбокомпресора (TK);

- динамічну модель ротора ВТ з гідрогальмом $(\mathrm{BT}+\Gamma \Gamma)$;

- динамічну модель ротора ВТ з несучим гвинтом (ВТ + НГ);

- динамічну модель РОВТ.

На сталих режимах завданням будь-якого регулятора є підтримка регульованого параметра на заданому рівні. Відхилення регульованого параметра від заданого значення парирується регулятором від- 
повідною зміною регулюючого чинника. У цьому випадку рівняння динаміки САР зручно розглядати в малих відхиленнях щодо базисної точки.

При математичному описі динаміки турбокомпресора і вільної турбіни було прийнято такі припущення [4]:

- інерційність процесів тепловиділення в камері згоряння в порівнянні з інерційністю роторів двигуна є несуттєвою;

- інерційність газодинамічних процесів, пов'язаних з накопиченням і випорожненням робочого тіла у внутрішніх порожнинах двигуна, $є$ несуттєвою;

- момент опору, що витрачаються на привід агрегатів і тертя в підшипниках, дуже малий.

3 урахуванням прийнятих припущень динаміку турбовального ГТД визначатимуть динаміка ротора ТК, ротора ВТ і РОВТ.

Модель динаміки ротора ТК.

Рівняння динаміки ротора турбокомпресора, що обертається має вигляд:

$$
\frac{\pi I_{T K}}{30} \frac{d n_{T K}}{d t}=M_{K}-M_{T},
$$

де $I_{T K}$ - приведений момент інерції ротора турбокомпресора;

$n_{T K}$ - оберти ротора ТК;

$M_{T}$ - крутний момент турбіни компресора;

$M_{K}$ - момент опору компресора.

У загальному вигляді моменти турбіни і компресора є складними функціями:

$$
\begin{aligned}
& M_{T}=M_{T}\left(n_{T K} ; G_{\Pi} ; P_{B}^{*} ; T_{B}^{*}\right) ; \\
& M_{K}=M_{K}\left(n_{T K} ; G_{\Pi} ; P_{B}^{*} ; T_{B}^{*}\right) ;
\end{aligned}
$$

де $G_{\Pi}$ - витрата палива;

$P_{B}^{*}-$ повний тиск повітря на вході в двигун;

$T_{B}^{*}$ - повітря на вході в двигун.

Для спрощення будемо вважати, що випробування двигуна проходять на землі в умовах стандартної атмосфери. Це дозволить на початковому етапі дослідження знехтувати впливом зміни зовнішніх умов $P_{B}^{*}$ і $T_{B}^{*}$.

3 урахуванням прийнятих припущень рівняння ротора ТК в лінійній постановці і в відносних змінних матиме вид:

$$
T_{T K} \dot{\bar{n}}_{T K}+\bar{n}_{T K}=K_{T K} \bar{G}_{T},
$$

де $T_{T K}-$ постійна часу ТК;

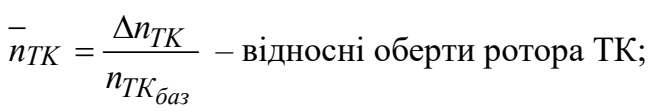

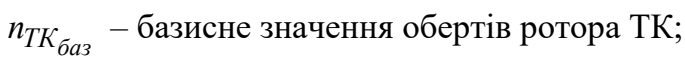

$\Delta n_{T K}-$ відхилення обертів ротора ТК від базисного значення;

$\dot{\bar{n}}_{T K}=\frac{d \bar{n}_{T K}}{d t}-$ відносна швидкість зміни обертів ротора TK;

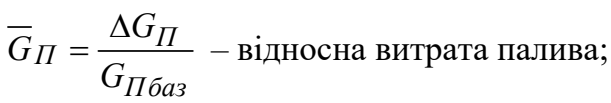

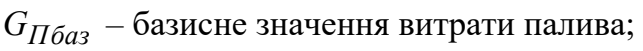

$K_{T K}$ - коефіцієнт підсилення витрати палива на оберти ТК.

Постійну часу турбокомпресора $T_{T K}$ можна наближено оцінити 3 динамічного аналізу роботи $\mathrm{CAP}\left(\mathrm{n}_{\mathrm{TK}}\right)$ по відомому значенню часу часткової приймальності, яка згідно інструкції екіпажу має складати:

- 9с від малого газу (МГ) до злітного режиму (3P);

- 4c від першого крейсерського (КР1) до 3Р;

- (3...6)с від малого газу до правої корекції (ПМГ);

Отже, постійна часу турбокомпресора буде перебувати в межах:

$$
T_{T K} \approx(1 \ldots 3), c \text {. }
$$

На рівноважних режимах $\frac{d \bar{n}_{T K}}{d t}=0$ i, як випливає 3 рівняння (4), коефіцієнт підсилення $K_{T K}$ дорівнює:

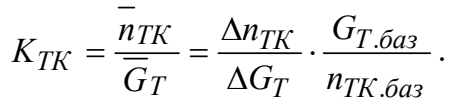

Отже, коефіцієнт підсилення $K_{T \kappa}$ можна визначити по експериментальної дросельній характеристиці двигуна (залежність параметрів двигуна від обертів ТК) (рис. 1).

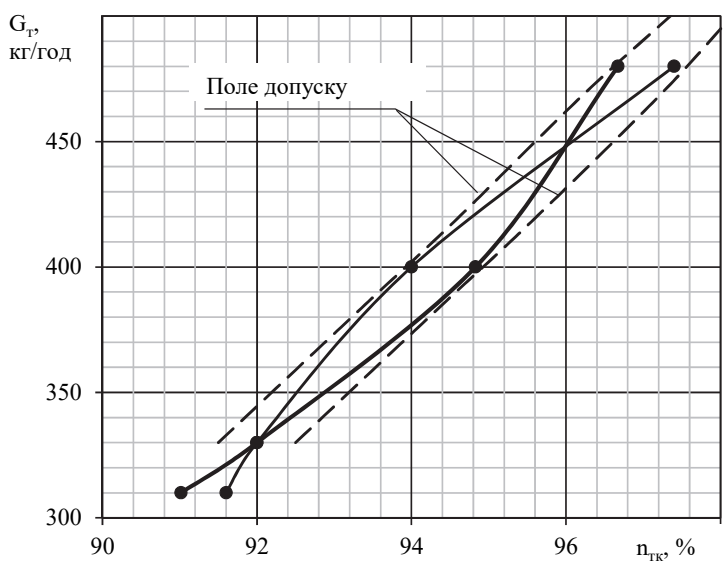

Рис. 1. Дросельна характеристика двигуна Джерело: розроблено авторами.

Однак, для проведення динамічних досліджень знання розрахункового значення коефіцієнта підси- 
лення ТК недостатньо. Необхідно знати ще можливий діапазон зміни цього коефіцієнта. Тому величина $K_{T K}$ розраховувалася з урахуванням поля допусків на зміну параметрів при проведенні моторних випробувань.

Зі зменшенням обертів ТК власна стійкість двигуна зменшується [7]. Тому розрахункова точка вибрана відповідною другому крейсерському режиму, як режиму з найменшим коефіцієнтом самовирівнювання. Для заданого поля допуску дросельної характеристики двигуна в області другого крейсерського режиму роботі турбокомпресора коефіцієнт підсилення ТК буде перебувати в межах:

$$
K_{T K}=0.124 \ldots 0.189 \text {. }
$$

Двигун з більшім значенням в коефіцієнта підсилення ТК по витраті палива в подальшому будемо називати “гострим”, а з меншим - “тупим”.

Модель динаміки ротора ВТ.

Рівняння динаміки ротора вільної турбіни з ГГ:

$$
\frac{\pi I_{(B T+\Gamma \Gamma)}}{30} \frac{d n_{B T}}{d t}=M_{B T}-M_{\Gamma \Gamma},
$$

де $I_{(B T+\Gamma \Gamma)}$ - приведений момент інерції ротора вільної турбіни і ротора гідрогальма;

$n_{B T}$ - оберти ротора ВТ;

$M_{B T}-$ крутний момент ВТ;

$M_{\Gamma Г}-$ момент опору ГГ.

Рівняння динаміки ротора вільної турбіни з НГ:

$$
\frac{\pi I_{(B T+H \Gamma)}}{30} \frac{d n_{B T}}{d t}=M_{B T}-M_{H \Gamma},
$$

де $I_{(B T+H \Gamma)}$ - приведений момент інерції ротора вільної турбіни и ротора НГ;

$M_{H \Gamma}$ - момент опру НГ.

У загальному вигляді крутний момент вільної турбіни, і моменти опору ГГ і НГ є складними функціями:

$$
\begin{gathered}
M_{B T}=M_{B T}\left(n_{B T} ; n_{T K} ; P_{B}^{*} ; T_{B}^{*}\right) ; \\
M_{\Gamma \Gamma}=M_{\Gamma \Gamma}\left(n_{B T} ; \alpha_{\Gamma \Gamma} ; t_{B}\right) ; \\
M_{H \Gamma}=M_{H \Gamma}\left(n_{B T} ; \varphi_{H \Gamma} ; P_{B}^{*} ; T_{B}^{*}\right),
\end{gathered}
$$

де $t_{B}$ - температура води на вході в ГГ;

$\alpha_{\Gamma \Gamma}-$ положення крану, що регулює витрату води ГГ;

$\varphi_{H \Gamma}-$ кут установки лопатей НГ.

Оскільки при випробуваннях системи автоматичного регулювання обертів ВТ завантаження гідрогальма або НГ не змінюється:

$$
\alpha_{\Gamma \Gamma}=\text { const }, \varphi_{H \Gamma}=\text { const },
$$

а також беручи до уваги прийняті раніше допущення, рівняння динаміки ротора ВТ в лінійній постановці і в відносних змінних для об'єкта (ВТ + ГГ) матиме вид:

$$
T_{\Gamma \Gamma} \dot{\bar{n}}_{B T}+\bar{n}_{B T}=K_{\Gamma \Gamma / n_{T K}} \bar{n}_{T K},
$$

де $T_{\Gamma Г}-$ постійна часу ротора (ВТ+ГГ), с;

$\bar{n}_{B T}-$ відносні оберти ротора ВТ;

$\dot{\bar{n}}_{B T}=\frac{d \bar{n}_{B T}}{d t}-$ відносна швидкість зміни обер-

тів ротора $\mathrm{BT}$;

$K_{\Gamma Г / n_{T K}}=\frac{\Delta \bar{n}_{B T}}{\Delta \bar{n}_{T K}}=K_{\Gamma \Gamma}-$ коефіцієнт підсилен-

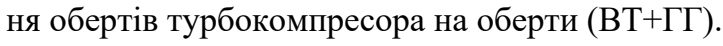

Рівняння динаміки в лінійній постановці для об'єкта (ВТ+НГ):

$$
T_{H \Gamma} \dot{\bar{n}}_{B T}+\bar{n}_{B T}=K_{H \Gamma / n_{T K}} \bar{n}_{T K},
$$

де $T_{H \Gamma}-$ постійна часу ротора (ВТ $+\mathrm{H \Gamma ),} \mathrm{c;}$

$$
K_{H \Gamma / n_{T K}}=\frac{\Delta \bar{n}_{B T}}{\Delta \bar{n}_{T K}}=K_{H \Gamma}-\text { коефіцієнт підсилен- }
$$
ня обертів турбокомпресора на оберти (ВТ $+\mathrm{HГ})$.

Як показав аналіз, рівняння динаміки $(\mathrm{BT}+$ ГГ) i $(\mathrm{BT}+\mathrm{HГ})$ за структурою однакові, але динамічні параметри різні.

Значення коефіцієнтів підсилення $K_{H \Gamma}$ та $K_{\Gamma \Gamma}$ можна визначити з завантажувальних характеристик НГ и ГГ (рис. 2):

$$
K_{H \Gamma}=\left(\frac{\Delta \bar{n}_{B T}}{\Delta \bar{n}_{T K}}\right)_{H \Gamma}, \quad K_{\Gamma \Gamma}=\left(\frac{\Delta \bar{n}_{B T}}{\Delta \bar{n}_{T K}}\right)_{\Gamma \Gamma} .
$$

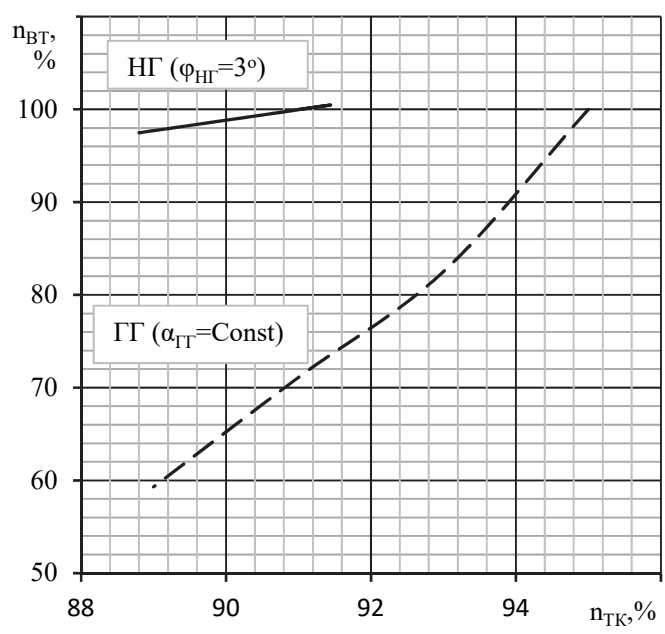

Рис. 2. Завантажувальна характеристика НГ та ГГ Джерело: розроблено авторами.

3 рис. 2 видно, що об'єкт (ВТ+ГГ) набагато “гостріше" реагує на зміну обертів (потужності) двигуна, ніж об'єкт (ВТ + НГ). Тобто приріст обертів ВТ при однаковій зміні обертів ТК у гідрогальма більше, ніж у НГ:

$$
K_{H \Gamma}=1,5 ; \quad K_{\Gamma \Gamma}=2,5 \ldots 4 .
$$


Постійні часу $T_{\Gamma \Gamma}$ и $T_{H \Gamma}$ визначалися $з$ аналізу динамічних процесів при моторних випробуваннях двигуна на ГГУ і в складі вертольота і приймалися наступними:

$$
T_{H \Gamma}=2, c, ; \quad T_{\Gamma \Gamma}=0,8, c .
$$

\section{Модель динаміки РОВТ.}

Динаміка РОВТ визначається процесами наповнення і спорожнення порожнин гідроприводу основної дозуючої голки (ОДГ) насоса-регулятора. В цьому випадку лінійне рівняння динаміки РОВТ може бути представлено у вигляді [2]:

$$
T_{P O B T} \bar{G}_{\Pi}+\bar{G}_{\Pi}=K_{P O B T} \bar{\varepsilon},
$$

де $T_{P O B T}-$ постійна часу;

$\kappa_{P O B T}-$ коефіцієнт підсилення;

$\bar{\varepsilon}=\left(\bar{n}_{B T . з а д}-\bar{n}_{B T}\right)-$ сигнал неузгодженості, що формується тахометром;

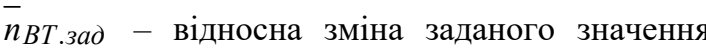
обертів ВТ, що формується механізмом настройки.

Постійну часу $T_{P O B T}-$ можна визначити з перекладки основної дозуючої голки (ОДГ) регулятора. Оскільки динаміка РОВТ описується лінійним диференціальним рівнянням першого порядку (13), то для цього випадку постійну часу РОВТ можна визначити за формулою:

$$
T_{\text {РОвТ }}=T_{\text {ОдГ }}=\frac{t_{R . О Д Г}}{3},
$$

де $t_{R . O Д Г}$ - час “перекладки” ОДГ при ступінчатому сигналі перенастроювання.

Згідно 3 протоколом приймально-здавальних випробувань заводу виробника час перекладки ОДГ має бути не більше 4 с. (Зазвичай 2 ... 2,1с), отже:

$$
T_{\text {РОВT }}=\frac{t_{R . О Д Г}}{3}=\frac{2 \ldots 4}{3}=(0,66 \ldots 1,33), c .
$$

Коефіцієнт підсилення РОВТ можна визначити по статичній характеристиці регулятора:

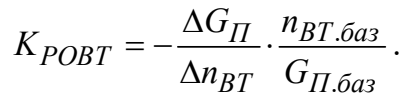

Відповідно до технічних умов на виготовлення насоса-регулятора, коефіцієнт підсилення РОВТ може змінюватися в межах: $K_{P O B T}=16 \ldots 30$. Однак, як показали експериментальні дослідження [3], реальні статичні характеристики РОВТ складні і містять зону нечутливості (гістерезис), обумовлену силами тертя в гідроприводі ОДГ, а також можуть містити нелінійні ділянки (“розриви” і “злами”), пов'язані з дефектами елементів насосу-регулятору.

Розглянемо рух робочої точки на реальної характеристиці регулятору обертів вільної турбіни При випадковому зменшенні обертів (рис. 3).

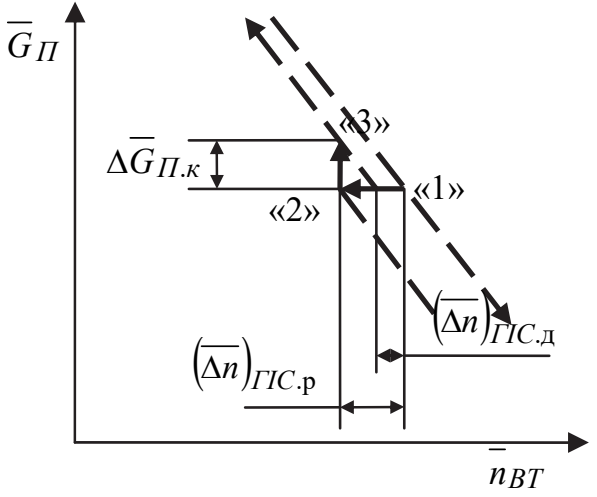

Рис. 3. Рух робочої точці РОВТ Джерело: розроблено авторами.

Припустимо, що рівноважний режим знаходиться в точці “1”. При випадковому зменшенні обертів робоча точка проходить зону нечутливості відповідно з розрахунковою величиною гістерезису, i рухається горизонтально від точки “1" до точки “2”. У точці “2” режим течії в керуючому клапані РОВТ змінюється і робоча точка переходить в точку “3”. В результаті формується ступенева зміна витрати палива - “кидок” палива на величину:

$$
\Delta \bar{G}_{\Pi . \kappa}=\left((\overline{\Delta n})_{\text {ГГС.p }}-(\overline{\Delta n})_{\text {ГІС.д }}\right) \cdot K_{\text {РОВT }},
$$

де $(\overline{\Delta n})_{\text {ГІС.P }} \approx 0,01$ - відносна розрахункова величина гістерезису, що визначається технічними умовами (ТУ);

$(\overline{\Delta n})_{\text {ГІС.д }}-$ відносна дійсна величина гістерезису, що визначається в експерименті.

Розрив характеристики РОВТ і кидок палива моделюється формуванням ступінчастої еквівалентної динамічної “добавки” до помилки регулювання:

$$
\bar{\varepsilon}_{Д}=(\overline{\Delta n})_{\text {ГІС.p }}-(\overline{\Delta n})_{\text {ГІС.д }} .
$$

$\mathrm{У}$ разі якщо дійсний гістерезис дорівнює розрахунковому значенню $(\overline{\Delta n})_{\text {ГІС.p }}=(\overline{\Delta n})_{\text {ГІС.д }}$, то динамічна добавка приймається рівною нулю $(\bar{\varepsilon}$ д $=0)$. Для одностороннього розриву характеристики динамічна добавка $\bar{\varepsilon}$ д формується за одностороннього виходу робочої точки з зони нечутливості, а при двосторонньому розриві добавка формується при виході робочої точки з зони нечутливості в обидві сторони. За результатами математичного опису елементів було складено структурнодинамічну схему системи автоматичного регулювання обертів вільної турбіни САР(n $\left.\mathrm{n}_{\mathrm{BT}}\right)$. (рис. 4).

У структурно-динамічну схему включено три нелінійних блоки. Блок із зоною нечутливості, що 
дозволяє моделювати гістерезис $(\overline{\Delta n})_{\text {ГІС.д }}$ реальної характеристики РОВТ. Релейний блок, що забезпечує моделювання нелінійної динамічної добавки $\overline{\varepsilon_{\partial}}$ до помилки регулювання і формування кидка палива в разі передбачуваного розриву реальної характеристики РОВТ. Блок вибору максимального і мініма- льного значення коефіцієнту підсилення РОВТ $\left(K_{P O B T_{M A X}}\right.$ OR $\left.K_{P O B T_{M I H}}\right)$ в залежності від знака сигналу неузгодженості $\bar{\varepsilon}$, що дозволяє моделювати злам реальної характеристики.

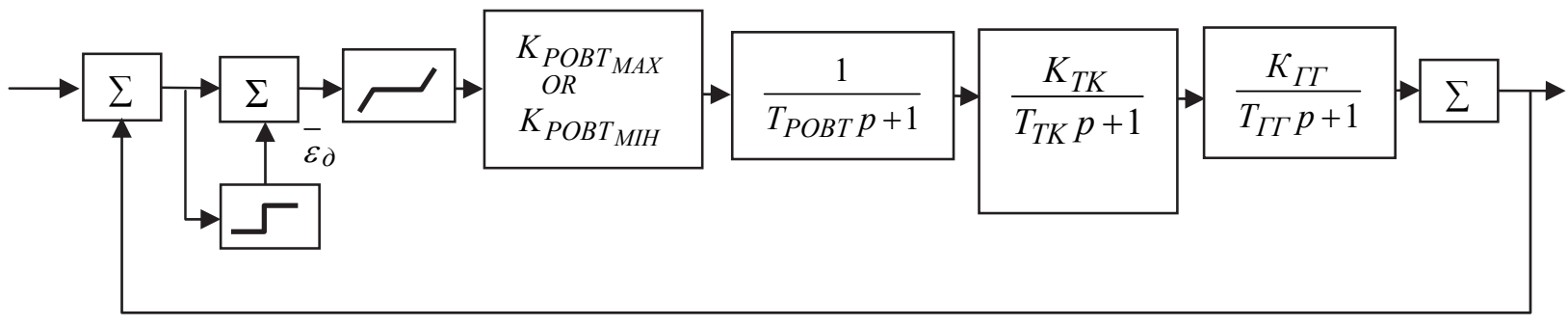

Рис. 4. Структурно-динамічна схема САР $\left(\mathrm{n}_{\mathrm{BT}}\right)$

Джерело: розроблено авторами.

Таким чином, в структурно-динамічної схемі враховані всі можливі параметри реальної $\mathrm{CAP}\left(\mathrm{n}_{\mathrm{BT}}\right)$. При дослідженні динаміки $\mathrm{CAP}\left(\mathrm{n}_{\mathrm{BT}}\right)$ з об'єктом (BТ + ГГ) в якості вихідної точки для проведення подальшого аналізу були обрані середні значення динамічних параметрів елементів:

$$
\begin{array}{cl}
K_{T K}=1,55 ; & T_{T K}=1,2, c ; \\
K_{\Gamma \Gamma}=2,5 ; & T_{\Gamma \Gamma}=0,5, c ; \\
K_{P O B T}=21 ; & T_{P O B T}=0,7, c ;
\end{array}
$$

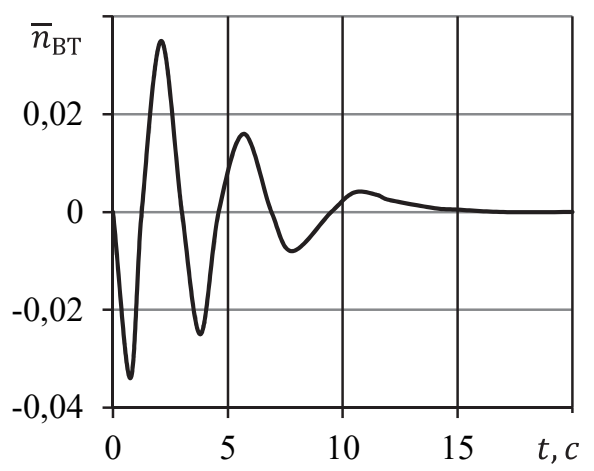

$\mathrm{a}-\mathrm{K}_{\mathrm{POBT}}=17$

$$
(\overline{\Delta n})_{\text {ГІС.д }}=(\overline{\Delta n})_{\text {ГІС.p }}=0,01 .
$$

У якості збурюючого впливу обрано короткочасну (протягом 1с) зміну обертів ротора ВТ на $2 \%$, викликану зміною заданого значення обертів вільної турбіни.

Вплив коефіцієнту підсилення РОВТ на вагові характеристики САР $\left(\mathrm{n}_{\mathrm{BT}}\right)$ з об'єктом $(\mathrm{BT}+\Gamma Г)$ показано на рис. 5. Значення параметрів ТК і ГГ обрані середніми (16).

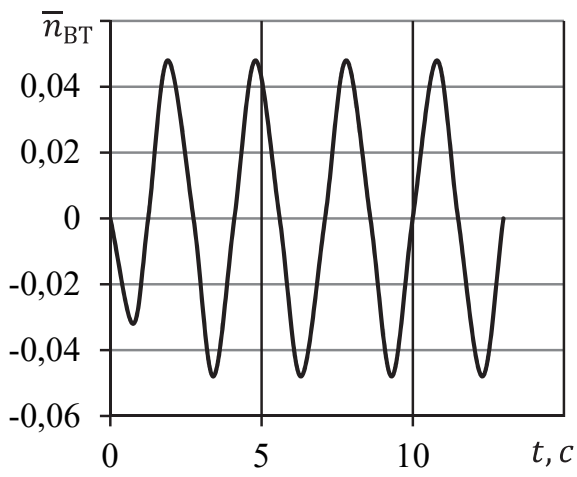

$6-\mathrm{K}_{\mathrm{POBT}}=28$

Рис. 5. Вплив К

Джерело: розроблено авторами.

3 рис. 5 видно, що для об'єкту регулювання $(\mathrm{BT}+Г Г)$ при коефіцієнті підсилення $K_{P O B T} \approx 17$ вагова характеристика загасаюча (рис. 5, а), при коефіцієнті підсилення $K_{P O B T} \approx 28$ коливання стають незгасаючими (рис. 5, б). При значеннях $K_{P O B T}>28$ амплітуда коливань безперервно наростає (система стає нестійкою). Таким чином можна зробити висновок, що зі збільшенням коефіцієнту підсилення РОВТ схильність САР $\left(\mathrm{n}_{\mathrm{BT}}\right)$ до коливань різко зростає. Для зменшення схильності агрегатів
НР-3 до розвитку автоколивань при моторних випробуваннях необхідно зменшувати коефіцієнт підсилення РОВТ.

Згідно вимог конструкторської документації заводу виготовлювачу насосів-регуляторів коефіцієнт підсилення РОВТ може змінюватися в досить широких межах $\left(K_{P O B T}=16 \ldots 30\right)$. Тобто реальні коефіцієнти підсилення регуляторів обертів вільної турбіни можуть находитися у межах недопустимих значень. Тому слід очікувати що при припустимих 
значеннях коефіцієнту підсилення РОВТ можливі не тільки автоколивання при наземних випробуваннях двигунів на гідрогальмівних установках, але і нестійка робота ї системі автоматичного регулювання обертів вільної турбіни.

Вплив коефіцієнту підсилення ТК. Динамічні параметри турбокомпресору також можуть змінюватися в межах поля допуску дросельної характеристики. Коефіцієнт підсилення ТК може змінюватися у досить широких межах, що неминуче вплине на вагові характеристики $\mathrm{CAP}\left(\mathrm{n}_{\mathrm{BT}}\right)$. В результаті при випробуваннях, один і той же регулятор буде по різному працювати 3 різними двигунами. При розрахункових дослідженнях значення параметрів POBТ і ГГ обрані середніми (16). На рис.6 показано результати розрахунку впливу коефіцієнту підсилення ТК на вагову характеристику САР $\left(\mathrm{n}_{\mathrm{BT}}\right)$ з об'єктом (ВТ + ГГ).

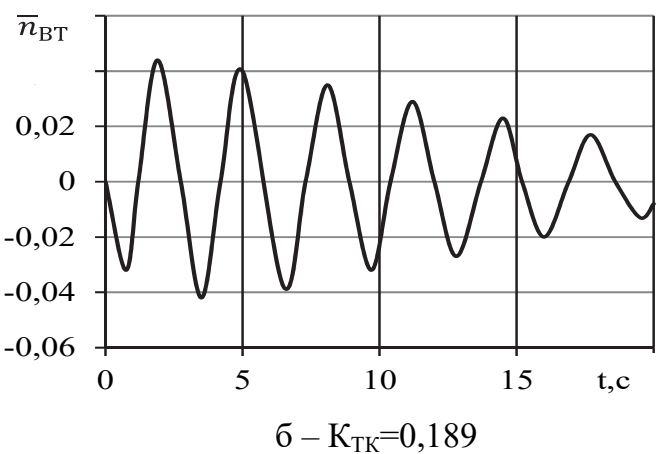

Рис. 6. Вплив КТК на вагові характеристики САР(nBT) з об'єктом (ВТ+ГГ) Джерело: розроблено авторами.

3 рис. 6 видно, що з “тупим” двигуном, що має коефіцієнт підсилення $K_{T K}=0,12$, РОВТ із середніми динамічними параметрами працює задовільно (вагова характеристика загасаюча рис. 6 , а), а в складі “гострого" двигуна $\left(K_{T K}=0,18\right)$ цей же регулятор працює незадовільно (вагова характеристика не згасає більше 20c рис. 6, б). Таким чином, для конкретного двигуна 3 певними динамічними параметрами існують допустимі значення коефіцієнта підсилення POBТ, перевищення яких приводить до розвитку автоколивань. Для аналізу схильності агрегатів до розвитку автоколивань при моторних випробуваннях, практичний інтерес представляє залежність допустимих значень коефіцієнту підсилення регулятора обертів вільної турбіни $\left.K_{\text {Ровт.доп }}\right)$ для різноманітних значень коефіцієнта підсилення ТК $\left(K_{T K}\right)$ (рис. 7).

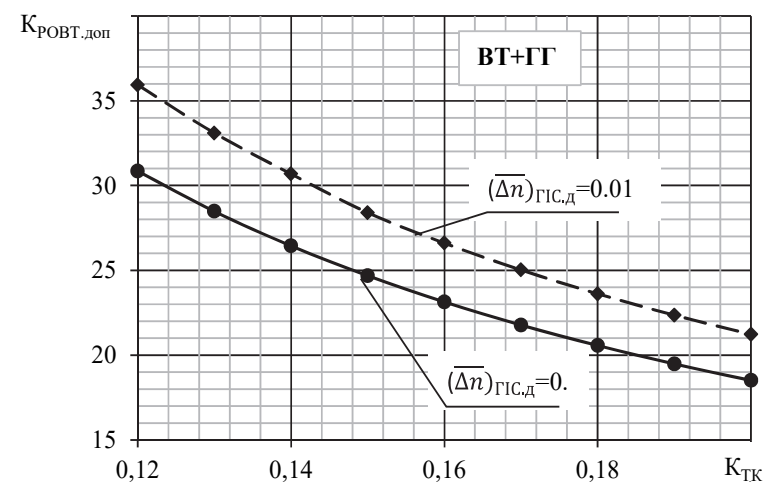

Рис. 7. Область допустимих значень К для об'єкту (ВТ+ГГ)

Джерело: розроблено авторами.
У розрахунках динамічна добавка (15) не враховувалася. Видно, що для двигуна із середнім коефіцієнтом підсилення $K_{T K}=1,55$, коефіцієнт підсилення регулятора обертів вільної турбіни повинен бути не більше $K_{P O B T} \leq 24,5$. 3 урахуванням гістерезису характеристики РОВТ допустимий коефіцієнт підсилення зростає до значень $K_{P O B T} \leq 28$. Таким чином, щоб забезпечити стійку роботу “гострих" двигунів 3 коефіцієнтом підсилення $K_{T K}=1,89$, потрібні ще менші значення коефіцієнтів підсилення POВТ, не більше $K_{\text {РОвт }} \leq 19$.

Як було показано вище, динамічні параметри НГ значно відрізняються від аналогічних параметрів ГГУ. Тому було виконано дослідження динаміки CAP $\left(\mathrm{n}_{\mathrm{BT}}\right)$ з об'єктом регулювання $(\mathrm{BT}+\mathrm{HГ})$. На рис. 8 показані порівняльні розрахункові дані зна-

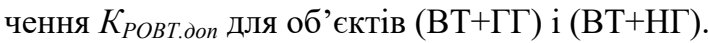

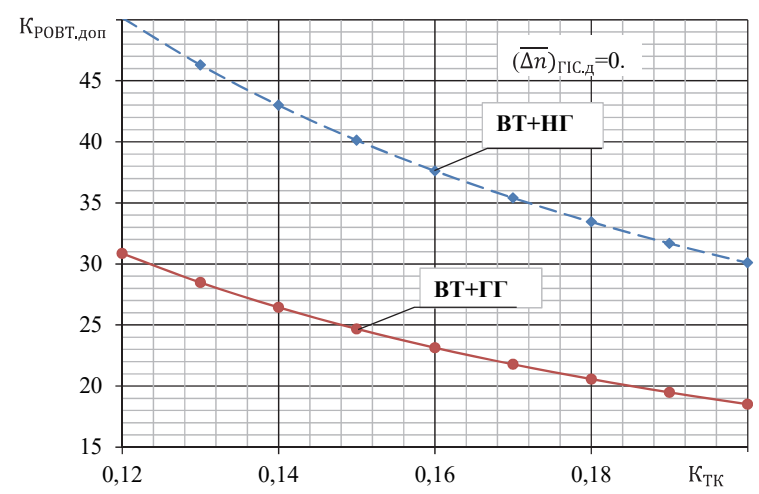

Рис. 8. Область допустимих значень КРовт.доп для об’єктів (ВТ+ГГ) та (ВТ+НГ) Джерело: розроблено авторами. 
У якості вихідної точки для порівняльного аналізу було обрано такі значення динамічних параметрів $\left.\mathrm{CAP}\left(\mathrm{n}_{\mathrm{BT}}\right):(15)\right)$ :

$$
\begin{aligned}
& K_{T K}=1,55 ; \quad T_{T K}=1,2, c ; \\
& K_{H \Gamma}=1,5 ; \quad T_{H \Gamma}=1,5, c ; \\
& K_{P O B T}=21 ; \quad T_{P O B T}=0,7, c ; \quad(\overline{\Delta n})_{\text {ГІС.д }}=0,0 .
\end{aligned}
$$

Видно, що при роботі РОВТ з об'єктом (ВТ + НГ) область допустимих значень значно ширше. Всі регулятори 3 коефіцієнтами підсилення 3 області допустимих значень $K_{P O B T}=16 \ldots 30$ стійко працюють 3 об'єктом (ВТ + НГ). У той же час при роботі РОВТ 3 об'єктом (ВТ + ГГ) регулятори $з$ коефіцієнтом підсилення $K_{P O B T}>22$, можуть працювати нестабільно 3

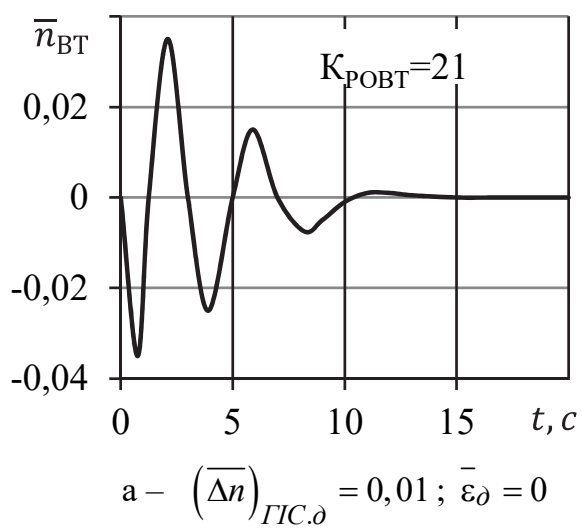

двигунами, які мають середні і вищі показники за коефіцієнт підсилення $K_{T K}>1,55$.

Вплив розриву характеристики РОВТ. Характеристики РОВТ можуть мати розриви першого роду (ступеневу зміну витрати палива при плавній зміні обертів ВТ). При дослідженні впливу дефекту “розрив”, динамічна добавка до помилки регулювання враховувалась і розраховувалася за формулою (15). На рис. 9 показаний порівняльний аналіз впливу “розриву” характеристики РОВТ на вагову характеристику CAP $\left(\mathrm{n}_{\mathrm{BT}}\right)$ з об'єктом (ВТ $\left.+Г Г\right)$, з середніми динамічними параметрами в досліджуваній точці (16). В даному дослідженні динамічна добавка приймалася максимальною $\bar{\varepsilon}$ д $=0,01$.

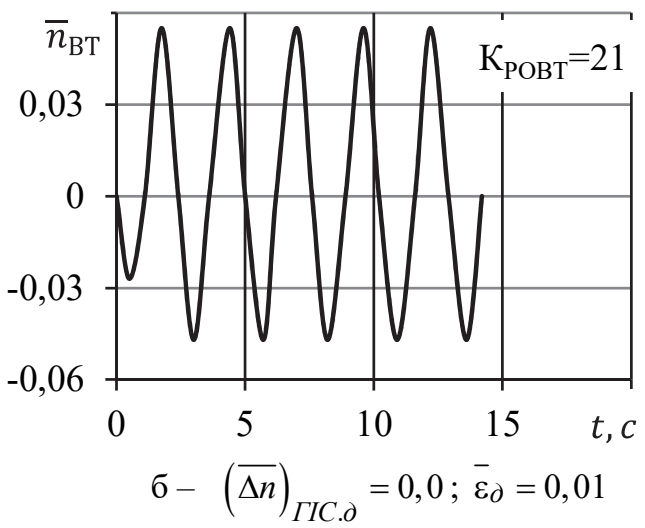

Рис. 9. Вплив “розриву” на характеристики РОВТ с об’єктом (ВТ+ГГ) на вагову характеристику САР $\left(\mathrm{n}_{\mathrm{BT}}\right)$ Джерело: розроблено авторами.

Видно, що регулятор вільної турбіни насосу регулятору без розриву характеристики має задовільну вагову характеристику (рис. 9, а) (характеристика коливальна, загасаюча). У той же час “розрив” характеристики регулятору призводить до розвитку автоколивань (рис. 9, б).

Для діагностування автоколивань практичний інтерес представляють дослідження співвідношення допустимих значень гістерезису і коефіцієнта підсилення характеристики РОВТ, що забезпечують відсутність розвитку автоколивань в $\mathrm{CAP}\left(\mathrm{n}_{\mathrm{BT}}\right)$. На рис. 10 представлені результати розрахункових досліджень для об'єкта $(\mathrm{BT}+\Gamma Г)$. Дуже істотний вплив на дане співвідношення має коефіцієнт підсилення двигуна. Якщо для “тупого” двигуна з коефіцієнтом підсиленням $K_{T K}=0,12$ відсутність автоколивань забезпечують РОВТ з коефіцієнтом підсилення $K_{P O B T} \leq 30 \quad$ та величиною гістерезису $0,006 \leq(\overline{\Delta n})_{\text {ГІС.д }} \leq 0,01$, то для двигуна зі середнім коефіцієнтом підсилення $K_{T K}=0,155$ забезпечити відсутність автоколивань може тільки РОВТ з гістерезисом більше 0,015 , що суперечить ТУ, або виникає потреба в обмеженні коефіцієнта підсилення POBT.

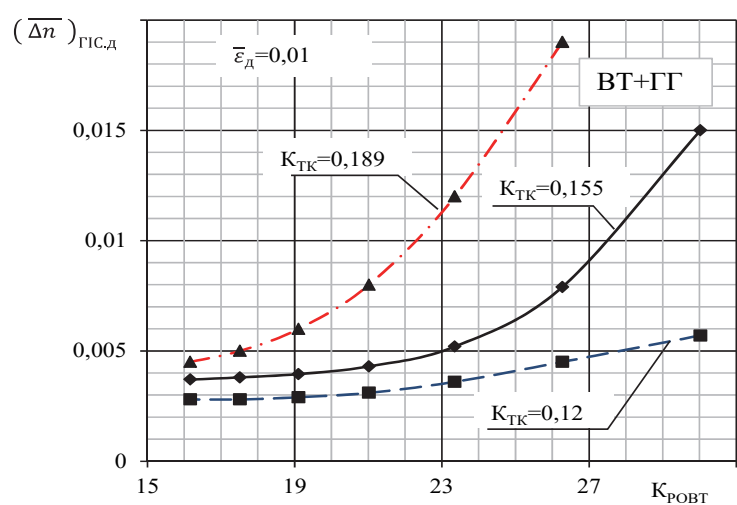

Рис. 10. Допустимі значення гістерезису i коефіцієнта підсилення РОВТ САР $\left(\mathrm{n}_{\mathrm{BT}}\right)$ з об'єктом (ВТ+ГГ) Джерело: розроблено авторами.

Таким чином, для “гострого” двигуна з коефіцієнтом підсилення $K_{T K}=0,189$ забезпечити відсутність автоколивань при випробуваннях двигуна на ГГУ можливо тільки при обмеженні коефіцієнта підсилення РОВТ. 


\section{Висновки}

1. Розроблено математичну модель динаміки системи автоматичного регулювання обертів вільної турбіни турбовальних газотурбінних двигунів при їх наземних випробуваннях на гідрогальмівних установках 3 урахуванням реальних завантажувальних характеристик гідрогальмівної установки, несучого гвинта вертольоту та статичних характеристик регуляторів. Розроблена модель може бути використана для досліджень динаміки системи автоматичного регулювання обертів несучого гвинта дводвигуневої силової установки вертольоту.

2. На підставі розрахункових досліджень виявлені основні залежності впливу динамічних параметрів елементів $\mathrm{CAP}\left(\mathrm{n}_{\mathrm{BT}}\right)$ на розвиток автоколивань при наземних випробуваннях двигунів типу ТВ3-117 на гідрогальмівних установках, що не мають автоматизованих систем управління завантаженням та визначені несприятливі поєднання динамічних параметрів елементів САР. Виявлені закономірності дозволяють діагностувати схильність насосів регу- ляторів НР-3 до розвитку автоколивань без проведення моторних випробувань.

3. Встановлені причини розвитку автоколивань в системі автоматичного регулювання обертів вільної турбіни турбовальних газотурбінних двигунів типу ТВ3-117 при їх наземних випробуваннях на неавтоматизованих гідрогальмівних установках, це:

- незадовільні характеристики регуляторів обертів вільної турбіни агрегатів типу НР-3 (розриви, злами, надлишковій коефіцієнт підсилення у точці дослідження, недостатнє значення величини гістерезису);

- невідповідність динамічних параметрів гідрогальмівних установок динамічним параметрам несучих гвинтів вертольотів;

- невідповідність характеристик регуляторів обертів вільної турбіни насосу регулятору типу НР3 динамічним параметрам двигуна ТВ3-117.

\section{Список літератури}

1. Системы автоматического управления авиационными ГТД: монография / под ред. д.т.н., проф. О.С. Гуревича. М.: ТОРУС ПРЕСС, 2011. - 207 c.

2. Development of an automated hydraulic brake control system for testing aircraft turboshaft gas turbine engines / P. Kachanov, O. Lytviak, O. Derevyanko, S. Komar // Eastern European Journal of Enterprise Technologies. - 2019. - No. 6/2(102). - P. 52-57. htps://doi.org/10.15587/1729-4061.2019.185539.

3. Литвяк О.М. Особливості статичних характеристик регулятора обертів вільної турбіни насосу-регулятора типу НР-3 / О.М. Литвяк, С.В. Комар // Системи озброєння і військова техніка. - 2020. - №4(64). - С. 93-100. https://doi.org/10.30748/soivt.2020.64.12.

4. Сосунов А.В. Неустановившиеся режимы работы авиационных газотурбинных двигателей / А.В. Сосунов, Ю.А. Литвинов. - М.: Машиностроение, 1975. - 215 с.

5. Волков В.В. Динамика нелинейных механических систем / В.В. Волков, А.Д. Семёнов. - Пенза: Пензенский гос. технологический университет, 2015. - $121 \mathrm{c}$.

6. Дедеш В.Т. Устойчивость и автоколебания нелинейных одноконтурных систем автоматического управления / В.Т. Дедеш // Ученые записки ЦАГИ. - 2010. - № 3, Том.42. - С. 82-92.

7. Грушун А.И. Анализ на ЭВМ автоколебаний в нелинейных системах автоматического управления на основе метода гармонического баланса / А.И. Грушун, Т.А. Грушун // Вістник СЕВНТУ. - 2020. - №146. - С. $223-225$.

8. Туманов М.П. Исследование колебания в системах управления с переменой структурой с учетом запаздывания / М.П. Туманов, С.Р. Абдуллин, П.С. Серебренников // Вестник Московского государственного университета леса. - 2020. - №1. - C. 20-30. https://doi.org/10.18698/2542-1468-1-117-123.

9. Detection of Oscillating Control Loops / S. Karra, M. Jelali, M. Karim, A. Horch // Detection and Diagnosis of Stiction in Control Loops: State of the Art and Advanced Methods - London: Springer, 2009. - 449 p.

10. Shoukat Choudhury M.A.A. Diagnosis of Process Nonlinearities and Valve Stiction / M.A.A. Shoukat Choudhury, Sirish L. Shah, Nina F.Thornhill. - London: Springer, 2008. - 308 p.

11. Frequency analysis and compensation of valve stiction in cascade control loops / Li Chen, M.A.A. Shoukat Choudhury, B. Huang, F. Qian // Journal of Process Control. - 2014. - Vol. 24, Is. 11. - P. 1747-1760. https://doi.org/10.1016/j.jprocont.2014.09.009.

12. Savelyev D.O. Stabilizing the Transients in the Objects and Systems Controlling the Compensation of Nonlinear ACS (Automatic Control System) Elements / D.O. Savelyev, A.S. Gudim, D. Solovev // International Science and Technology Conference "EastConf". - 2019. - P. 575-579. https://doi.org/10.1109/EastConf.2019.8725324.

13 Лубко Д.В. Проектування та розробка експертної системи діагностування несправностей транспортних засобів / Д.В. Лубко, О.Г. Зінов’єва, С.В. Шаров // Системи обробки інформації. - 2019. - № 1(156). - С. 15-21. https://doi.org/10.30748/soi.2019.156.02. 
Відомості про авторів:

Литвяк Олександр Миколайович

кандидат технічних наук доцент

доцент Національного університету

цивільного захисту України,

Харків, Україна

https://orcid.org/0000-0002-0242-1859

\section{Комар Сергій Володимирович}

кандидат технічних наук доцент

доцент Харківського національного університету

Повітряних Сил імені. Івана Кожедуба,

Харків, Україна

https://orcid.org/0000-0002-8961-2614
Information about the authors:

Oleksandr Lytviak

Candidate of Technical Sciences Associate Professor

Senior Lecturer of National University

of Civil Defence of Ukraine,

Kharkiv, Ukraine

https://orcid.org/0000-0002-0242-1859

\section{Sergii Komar}

Candidate of Technical Sciences Associate Professor

Senior Lecturer of Ivan Kozhedub

Kharkiv National Air Force University,

Kharkiv, Ukraine

https://orcid.org/0000-0002-8961-2614

\title{
ПРОБЛЕМЫ НАЗЕМНЫХ ИСПЫТАНИЙ ТУРБОВАЛЬНЫХ ГАЗОТУРБИННЫХ ДВИГАТЕЛЕЙ ТИПА ТВЗ-117
}

\author{
А.Н. Литвяк, С.В.Комар
}

Одной из причин развития автоколебаний в системе автоматического регулирования свободной турбины является несоответствие загрузочных характеристик гидротормозной установки загрузочным характеристикам несущего винта вертолета. При наземных испытаниях объектом регулирования является свободная турбина с подключенным ротором гидротормоза. При работе двигателя в составе силовой установки вертолета объектом регулирования является свободная турбина с подключенным ротором несущего винта. Изменение параметров объекта регулирования без соответствующей коррекции параметров регулятора может привести к неудовлетворительной динамике системь автоматического регулирования. Другой причиной развития автоколебаний является нелинейность характеристик элементов системы автоматического регулирования. В статье представлена математическая модель системы автоматического регулирования оборотов свободной турбины, учитывающая нелинейные особенности характеристик реальных регуляторов. Проведены расчетные исследования влияния разрыва статической характеристики и зоны нечувствительности регулятора на развитие автоколебаний системе автоматического регулирования оборотов свободной турбины при наземных испытаниях вертолетного двигателя. Даны рекомендачии по выбору параметров регулятора оборотов свободной турбины для предотвращения возникновения и развития автоколебаний оборотов турбокомпрессора и свободной турбины.

Ключевые слова: турбовальный ГТД, свободная турбина, несущий винт вертолета, гидротормоз, регулятор оборотов свободной турбины, статическая характеристика регулятора, автоколебания.

\section{PROBLEMS OF GROUND TESTS OF TURBO SHAFT GAS TURBINE ENGINE TYPE TV3-117}

\section{O. Lytviak, S. Komar}

During ground tests of TV3-117 gas turbine engines on hydraulic brake systems, self-oscillations of the rotor speed of a free turbine and the parameters of a turbocharger in the area of operation of the free turbine speed regulator are often recorded. One of the reasons for the development of self-oscillations in the automatic control system of a free turbine is the discrepancy between the loading characteristics of the hydraulic braking unit and the loading characteristics of the helicopter main rotor. During ground tests, the object of regulation is a free turbine with a connected hydraulic brake rotor. When the engine is operating as part of a helicopter power plant, the control object is a free turbine with a connected main rotor rotor. Changing the parameters of the controlled object without appropriate correction of the controller parameters can lead to unsatisfactory dynamics of the automatic control system. Another reason for the development of self-oscillations is the nonlinearity of the characteristics of the elements of the automatic control system. The article presents a mathematical model of the system for automatic control of the speed of a free turbine, taking into account the nonlinear features of the characteristics of real regulators. Computational studies of the influence of the rupture of the static characteristic and the zone of insensitivity of the regulator on the development of self-oscillations in the automatic control system of the speed of a free turbine during ground tests of a helicopter engine are carried out. Recommendations are given on the choice of parameters of the free turbine speed regulator to prevent the occurrence and development of self-oscillations of the speed of the turbocharger and free turbine.

Keywords: turboshaft GTE, free turbine, helicopter main rotor, hydraulic brake, free turbine speed regulator, static characteristic of the regulator, self-oscillations. 